\title{
Pride and Prejudice: West Indian Men in Mid-Twentieth-Century Britain
}

\author{
Marcus Collins
}

Of all the immigrants arriving in Britain in the middle of the twentieth century, none attracted as much attention from whites as West Indian men. This was initially explicable by their being the first nonwhites to settle in large numbers. Around ten thousand arrived during the Second World War (more than Britain's entire prewar black population) and, although some two-thirds of them were hurriedly repatriated after 1945, returning ex-servicemen formed the majority of passengers disembarking from the Empire Windrush on 21 June 1948: year zero for mass black immigration. For the following decade, most of the Commonwealth immigrants coming to Britain each year were West Indian, and, of these, men outnumbered women by a ratio of roughly two to one. ${ }^{1}$

In the late 1950s and 1960s, as their womenfolk joined them and as South Asians formed an ever-increasing proportion of new arrivals, it became clear that the prominence of West Indian men was more than merely numerical. It was cultural, stemming from the fascination-cumrevulsion of whites who customarily regarded them as vicious, indolent, violent, licentious, and antifamilial. These qualities were thought to differentiate them from their South Asian counterparts, who overcame an unsavory reputation acquired in the fifties to be viewed as the new Jews, placid and hard-working family men whose strict endogamy nullified

Marcus Collins is Sir James Knott Fellow in History at the University of Newcastle. He wishes to thank Joanna Bourke, David Cannadine, Deborah Cohen, Victoria de Grazia, David Feldman, Ayesha Jalal, Winston James, Patrick McDevitt, Joe Meisel, Pat Myers, Tom Smith, Lisa Tiersten, Deborah Valenze, Chris Waters, and Sam Walker of the Black Cultural Archives for advice and support; and Columbia University, the Whiting Foundation, and Sir James Knott Fellowship for financial assistance during the writing of this article.

${ }^{1}$ These statistics are drawn from Ian R. G. Spencer, British Immigration Policy since 1939: The Making of Multi-Racial Britain (London, 1997), pp. 3, 18; and Mike Phillips and Trevor Phillips, Windrush: The Irresistible Rise of Multiracial Britain (London, 1998), p. 118.

Journal of British Studies 40 (July 2001): 391-418

(C) 2001 by The North American Conference on British Studies.

All rights reserved. 0021-9371/2001/4003-0004\$02.00 
their sexual charge. Much the same could be said for West Indian women, who posed less of a threat to white sensibilities on account of being considered less intemperate and sexually predatory than men. If Edward Said's Oriental "Other" was feminine, the Caribbean "Other" was anything but. ${ }^{2}$

Different strands of opinion fed into this white discourse. Journalists and the new profession of sociologists attempted to define the "problem" caused by mass immigration, while policy makers, philanthropists, and social workers sought in their various ways to solve it. Novelists dramatized the tensions of race relations; anthropologists placed them in their colonial context. And at the extremes stood proto-multiculturalists such as Colin MacInnes and unabashed racists - whether eugenicists, fascists, or Little Englanders. What united these otherwise disparate voices was their emphasis upon the difference of West Indians from whites, a contrast they found to be starkest in respect to masculinity. Whether bigots ranting against miscegenation, social scientists studying familial breakdown, or bohemians digging "Spades" out of sheer nostalgie de la boue, white commentators shared the notion that West Indian men constituted a "countertype" to that of whites. ${ }^{3}$

West Indians, however, were no silenced subalterns. They boasted their own academics, produced their own social workers, even sent over their own governmental commissions to study migrant life in Britain. Among the immigrants were also some of the Caribbean's finest creative writers, including the novelists Andrew Salkey and V. S. Naipaul and calypsonians of the stature of Lord Kitchener and The Mighty Terror. The views of more ordinary West Indians were first expressed in obscure memoirs and pamphlets, then found voice through interviews conducted by black and white sociologists, and continue to this day to be recorded by oral historians anxious to preserve the memories of a now-dwindling generation. Unrepresentative in the sense of being largely self-selected, and drawn disproportionately from Trinidad and Barbados, these commentators nonetheless strove to serve a representative function when correcting white misapprehensions or galvanizing their own community into action.

What they had to say mirrored nineteenth-century working-class autobiography in its attempt to establish the authors' own respectability in

${ }^{2}$ Edward Said, Orientalism (London, 1978), pp. 207-8. For West Indian women, see in particular Elyse Dodgson, Motherland: West Indian Women to Britain in the 1950s (London, 1984); and Ben Bousquet and Colin Douglas, West Indian Women at War: British Racism in World War II (London, 1991).

${ }^{3}$ For ethnic masculine "countertypes," see George Mosse, The Image of Man: The Creation of Modern Masculinity (New York, 1996), chap. 4. 
the face of prevailing prejudice. Representing themselves as threatened, not threatening, sinned against, not sinning, deskilled, not unskilled, respectable West Indian men contradicted white portrayals of them at every point. If such stereotypes had any validity, they claimed, it was only among a few "mad bastards" who "seemed to be acting [the] part" of the libertine at odds with their true nature. ${ }^{4}$ First generation commentators also initially underplayed the difference between black and white masculinity, instead portraying their countrymen as British citizens striving to conform to a quasi-British model of manhood. It was only once their experience of discrimination convinced them that their assimilationist quest was both impossible and undesirable that their masculine ideals became self-consciously blacker and more independent of metropolitan mores.

This article is concerned with the dissonance between black and white perceptions of West Indian men. Its time-frame extends from the 1930s to about 1970, after which point debates surrounding Ugandan Asians and British-born West Indians shifted attention away from the first cohort of West Indian immigrants. Its methodology parallels that of Mrinalini Sinha, Laura Tabili, and Catherine Hall in its concern with how the relationship between black and white men has been shaped by the power differentials present in colonial and postcolonial encounters. ${ }^{5}$ Its aim is first to establish what West Indians and whites thought of each other in the colonial setting before examining how the issues of employment, family life, sexuality, violence, and citizenship related to West Indian men. Certain mid-century issues concerning West Indian immigration are excluded. Housing was a relatively nongendered matter; cricket concerned "tourists" rather than British residents; and crime became a major concern only in the 1970 s. $^{6}$ Its argument is that the clashing conceptions of black masculinity between West Indians and whites formed an integral aspect of racial conflict in mid-twentieth-century Britain.

${ }^{4}$ Wallace Collins, Jamaican Migrant (London, 1965), p. 59. For respectability in working-class memoirs, see David Vincent, Bread, Knowledge and Freedom: A Study of Nineteenth-Century Working Class Autobiography (Cambridge, 1981).

${ }^{5}$ Mrinalini Sinha, Colonial Masculinity: The "Manly Englishman" and the "Effeminate Bengali" in the Late Nineteenth Century (Manchester, 1995); Laura Tabili, "We Ask for British Justice": Workers and Racial Difference in Late Imperial Britain (Ithaca, N.Y., 1994); Catherine Hall, White, Male and Middle Class (Cambridge, 1992), chaps. 9, 10 .

${ }^{6}$ For cricket, see Patrick F. McDevitt, "May the Best Man Win: Sport, Masculinity and Nationalism in Great Britain and the Empire, 1884-1939'" (Ph.D. diss., Rutgers University, 1999). For crime scares in the seventies, see Stuart Hall et al., Policing the Crisis: Mugging, the State and Law and Order (Basingstoke, 1978); and Paul Gilroy, There Ain't No Black in the Union Jack: The Cultural Politics of Race and Nation (London, 1992). 
White stereotypes of West Indian men were used to justify denying them jobs, refusing them dates, even attacking them in the streets. In consequence, many West Indian men felt alienated from the country in which they had chosen to live.

\section{The Colonial Context}

The interaction between whites and West Indians in the colonial Caribbean provided each group with conceptions of the other's masculinity well before mass migration. To colonial West Indians, British manhood was embodied in the figure of the gentleman, an idea which derived in part from romanticized visions of the metropole. Indoctrinated at school with tales of British "men of deeds brave and bold," of "Clive of India and Gordon of Khartoum," they came to imagine that Britain was "the home of gentlemen." 7 Their firsthand experience of white men confirmed rather than contradicted these odd impressions, for such was the nature of colonial rule that they "only had contact with gentlemen and the upper classes." In the colonies, after all, the British still had the wherewithal to live an "Upstairs, Downstairs" lifestyle and, as well as being financially feasible, a show of gentlemanliness was positively encouraged by colonial authorities eager to overawe their subjects. No wonder, then, that they were regarded by many West Indians as archetypal gentlemen: sporting, leisured, well-bred, well-read, reserved, and assured authority figures "strid[ing] in dignity down the street." 8

Gentlemanliness left colonial West Indians ambivalent. Trinidadian intellectual C. L. R. James could only admire his headmaster's "bristling Britishness" and "devoted, conscientious and self-sacrificing"' behavior, while the usually caustic calypsonian Atilla (aka Raymond Quevedo) was won over by the charm and paternalistic solicitude of Trinidad governor "His Excellency Sir Bede Clifford . . . the quintessence of courtesy." Admiration encouraged imitation among the West Indian middle class, who did their best to be "Europeans in dress . . . in tastes, in opinions

${ }^{7}$ E. Martin Noble, Jamaican Airman (London, 1984), p. 66; “"A West Indian Social Worker," in Race: A Christian Symposium, ed. Clifford S. Hill and David Mathews (London, 1968), p. 158; Ken cited in Donald Hinds, Journey to an Illusion: The West Indian in Britain (London, 1966), p. 15.

${ }^{8}$ Horace Ove cited in Edward Pilkington, Beyond the Mother Country: West Indians and the Notting Hill White Riots (London, 1988), p. 24; interview with William Strachan, Imperial War Museum (IWM) Sound Archive, 10042/5, reel 1; Leary Constantine, Colour Bar (London, 1954), p. 176. For the relationship between conceptions of gentlemanliness and the British national character during this period, see Marcus Collins, "The Fall of the English Gentleman: The National Character in Decline, c. 1918-70," Historical Research 74 (2001), in press. 
and in aspirations." 9 James's grandfather donned a "frock-coat, striped trousers and top hat," novelist George Lamming received training in how to be "A Gentleman," newsreader Trevor McDonald and his classmates were expected to become "British-educated lawyers or doctors," and mixed-race Jamaican William Strachan attended a mostly white public school kitted out in an Eton collar in accordance with his parents' desire to make him a "mock . . copy of English aristocrat." 10

The respect paid by upstanding West Indians to their interpretation of British masculinity came under challenge from the 1930s onward from nationalists intent on undermining colonial rule by disparaging British claims to gentlemanliness. Atilla led the assault, contemplating how imperial warriors like Marlborough and Wellington would have regarded Neville Chamberlain's betrayal of "the England of History" when "begging for peace" at Munich and portraying colonial officials as so many parasites "devoid of every semblance of decency." A more sophisticated exposition of the same theme was found in C. L. R. James's "The Case for West Indian Self-Government" (1933), in which the average British administrator was portrayed as suffering from a hollowing out of his true personality. Such a man arrived in the West Indies convinced of his superiority only to discover a "thoroughly civilised community, wearing the same clothes that he does, speaking no other language than his own, with its best men as good as and, only too often, better than himself."' Shocked and uneasily aware of the falsity of his position, the official would cling desperately to the trappings of gentlemanliness while losing much of the substance. His philistinism and "shallowness" would be exposed and he would dishonestly try "to make it appear as if he is . . a sportsman" (for James, the ultimate sin). The end product was the narrow-minded, cold-hearted, stiff-upper-lipped expat, a man diminished by his front of superiority and reduced to belittling West Indians to shore up his flagging self-esteem. ${ }^{11}$

Nationalists' attempts to create a distinctive West Indian identity ran up against their compatriots' deeply held identification with Britain as the "mother country." Many could not conceive of "any other way

${ }^{9}$ C. L. R. James, Beyond a Boundary (London, 1969), p. 38; Raymond Quevedo [aka Atilla], Atilla's Kaiso: A Short History of Trinidad Calypso (St. Augustine, 1983), p. 127; Eric Williams, The Negro in the Caribbean (Manchester, 1945), p. 40.

${ }^{10}$ James, Beyond a Boundary, p. 17; George Lamming, The Pleasures of Exile (London, 1960), p. 198; Trevor McDonald, Fortunate Circumstances (London, 1993), p. 21; interview with William Strachan, IWM Sound Archive, 10042/5, reel 1.

"Atilla cited in Gordon Rohlehr, Calypso and Society in Pre-Independence Trinidad (Port of Spain, 1990), p. 327; Quevedo, Atilla's Kaiso, p. 146; C. L. R. James, “The Case for West Indian Self-Government" (1933), in The Future in the Present: Selected Writings (London, 1977), pp. 29, 32; James, Beyond a Boundary, p. 125. 
of living, of thinking, of being" than Britishness and accordingly believed that British was best. "You could not be good on your own. Your good was no good. Your good has to be British," explained Jamaican Sam King. ${ }^{12}$ It was a tendency to which nationalists were themselves prone in that they sought to challenge not the gentlemanly ideal itself but, rather, the right of the British to establish sole possession over it. Their claim to citizenship was couched in the derivative language of manly virtue, with Norman Manley preaching the doctrine of self-help through Jamaica Welfare Limited, trade union activist Uriah Butler invoking the martial values of "service and sacrifice," and cricketer Learie Constantine portraying fellow blacks as being "in every sense of the word sportsmen." Through their eagerness to appropriate British gentlemanliness, nationalists paradoxically betrayed their subordination to it. So rested colonial West Indian attitudes to Britain and British masculinity: a love-hate relationship, part emulation, part denigration, amounting to fixation. ${ }^{13}$

Whereas colonial West Indians equated Britishness with gentlemanliness, the British tended to believe that the typical West Indian represented everything that the gentleman was not. The notion that the West Indian man was a slave to his passions can be traced back to The Tempest and formed the essence of Thomas Carlyle's case against the humanitarianism of missionaries and John Stuart Mill in the Victorian disputes over West Indian masculinity examined by Catherine Hall. ${ }^{14}$ The British governmental reports and anthropological surveys issued after the rebellions of 1937-39 retained some elements of Mill's and the missionaries' desire to release the inherent goodness of West Indian men from its environmental constraints, with due acknowledgment accorded to the disadvantages under which they labored. But overshadowing any reformism in these writings was a Carlylean indictment of the indolence and insolence of West Indian men. Of the three major "undesirable features" of West Indian society identified in the 1938-39 Royal Commission chaired by Lord Moyne- "the low status accorded to women, the lack of family life and the absence of a well-defined programme of social welfare" two were blamed firmly on them. Family instability was attributed by British observers to the "unscrupulous and improvident father ...

${ }^{12}$ Walter Lothen in The Windrush Legacy: Memories of Britain's Postwar Caribbean Immigrants (London, 1998), p. 25; E. R. Braithwaite, To Sir, with Love (London, 1967), pp. 38-39; Sam King cited in Phillips and Phillips, Windrush, p. 17.

${ }^{13}$ Uriah Butler cited in Eric Williams, History of the People of Trinidad and Tobago (London, 1963), p. 235; Constantine, Colour Bar, p. 163.

${ }^{14}$ Thomas Carlyle, The Nigger Question (London, 1853; reprint, New York, 1971); Hall, White, Male and Middle Class, chaps. 9, 10. 
evad[ing] his responsibilities towards his children and their probably unmarried mother." In the absence of a steady paternal influence, a boy fell victim to an "obsessive mother-son relationship" resulting, in anthropologist Edith Clark's opinion, in prolonged dependency, a "failure to develop satisfactory relationships with other people" and-to complete the vicious circle-no understanding of "his duty as a father." 15

British commentators likewise contended that the apparently low standing of women in the West Indies stemmed from their menfolk's determination to claim the privileges but renege on the duties of manhood. In this interpretation, West Indian men sought to control public life while failing to ensure that women were "specially protected" in the manner that they deserved. They demanded a family wage to support dependents whom they shamefully neglected, pleading "responsibilities that they shun in actuality." And they upheld a sexual double standard, their untrammeled license being responsible for the high birth rates and venereal disease afflicting the islands. "Eighty per-cent of the population is illegitimate, seventy per-cent (in several islands) have syphilis," claimed Clementine Churchill in 1939, noting elsewhere that "the Tories [on the Moyne Commission] want[ed] to do nothing but introduce birth control and even sterilization." 16

In addition to their reputation for promiscuity, patriarchy, and fatherly neglect, West Indian men were supposedly sorry workers. One official report issued in 1939 found it "most discouraging" to encounter the "prevailing absence of a spirit of independence and self-help, the lack of a tradition of craftsmanship and pride in good work, and a tendency in all matters to appeal to Government for assistance with little or no attempt to explore what can be done by individual self-help." The report excused West Indian women from much of its censure, commending them for the "very creditable fight" they undertook as mothers; indeed, women were often believed to undertake more paid work than was strictly good for them or their families. But British commentators expressed fears that casual employment was as much a consequence as a cause of West Indian men's laziness and lack of ambition. An incapacity to earn money was thought to be matched by a recklessness in spending it. Wages were gambled away or otherwise squandered, rarely reach-

${ }^{15}$ West India Royal Commission Report (London, 1945), pp. 230, 31; Edith Clarke, My Mother Who Fathered Me: A Study of the Family in Three Selected Communities in Jamaica (London, 1957), pp. 164, 163.

${ }^{16}$ T. S. Simey, Welfare and Planning in the West Indies (Oxford, 1946), p. 44; G. St. J. Orde Browne, Labour Conditions in the West Indies (London, 1939), p. 220; Clementine Churchill cited in Mary Soames, Clementine Churchill (Harmondsworth, 1981), pp. 399,400 . 
ing the men's dependents. This improvidence, together with their impression that "promiscuity and illegitimacy" made the woman the main family wage earner, made the Moyne Commission question whether a regular income would in itself either instill a work ethic in the man or alleviate the poverty of his wife and children. ${ }^{17}$

To cap it all, British writers argued that West Indian men had lost none of the "dangerous potentialities" displayed in the Governor Eyre Affair three quarters of a century before. ${ }^{18}$ Academic and wartime colonial official T. S. Simey viewed the anticolonial uprisings as evidence of West Indians' "baffling and contradictory" behavior, characterized by mood swings veering "from an easy-going acceptance of the shortcomings and misfortunes of existence to a mood of aggressiveness and a determination to redress grievances by energetic physical action." According to Simey's frustration-aggression model, West Indians used violence as a "safety-valve" for energies denied proper outlets of expression and not otherwise dissipated in sexual abandon. So long as their surroundings constrained their ambitions, they would remain forever volatile. $^{19}$

In sum, British observers adjudged colonial West Indian men to have flunked every test of masculine respectability. Slaves no longer, yet still in slavery's thrall, they appeared to have transmitted the familial dysfunction, sexual impropriety, and antiwork ethic that were its hallmarks down from one generation to the next. They were charged with working desultorily, fornicating wildly, fighting freely, and altogether failing to fulfill their most basic duties as fathers and breadwinners. But would such stereotypes perish or flourish when whites and West Indians met not under colonial rule in the Caribbean but in Britain itself? A provisional answer came in the Second World War, when thousands of mostly Jamaican men volunteered to be munitions workers and Royal Air Force ground crew stationed in Britain. Their white hosts, while generally appreciative of colonials' participation in the war effort, were nonetheless concerned that some West Indian men had enlisted in order to "escape from the burden of family responsibilities," were unimpressed by their work-skills (the Royal Ordnance Factory at Risley wished to sack them all for incompetence), and reportedly reacted with "sheer jealousy" when they dated white women. ${ }^{20}$ West Indian men

${ }^{17}$ Orde Browne, Labour Conditions, pp. 36, 38; West India Report, p. 18.

${ }^{18}$ Lord Olivier, The Myth of Governor Eyre (London, 1933), p. 16. For the classic account of the Governor Eyre Affair, see Bernard Semmel, The Governor Eyre Controversy (Boston, 1963).

${ }^{19}$ Simey, Welfare and Planning, pp. 98, 23.

${ }^{20}$ Anthony H. Richmond, Colour Prejudice in Britain: A Study of West Indian Workers in Liverpool, 1941-51 (London, 1954), p. 80; Superintendent of Risley Royal Ord- 
themselves, while generally appreciative of the respect accorded to them for their war work, nonetheless resented being denied dances by WAAFs and good jobs by armaments factories. Furthermore, they discovered that, having been "more or less welcomed [in wartime] because we were in the uniform of the King," the end of war made whites "constantly ask them when they are returning home." Hospitality had been forthcoming from whites for the duration only. ${ }^{21}$

A truer test came three years after the war, when some five hundred Jamaican men (and one woman stowaway) walked down the gangplank of the Empire Windrush. Mass migration allowed West Indians and whites to interact in a less circumscribed and artificial manner than had been the case either in wartime or the colonial Caribbean. Here, for the first time, West Indian men were exposed on a daily basis to what whites thought of them. Whites, meanwhile, gained the opportunity to assess West Indian men anew as workers, husbands, fathers, lovers, fighters, and potential British citizens. The result was conflict.

\section{Employment}

Like most migrants, West Indian men emigrated in order to work, generally deciding when to go and where to live according to the fluctuating demand for factory hands in England's major urban conurbations. Upon seeking employment in Britain, however, they found that whites doubted whether they were either willing to work or able to do so. Much of the prejudice they encountered derived from a reputation for workshyness acquired in the colonial West Indies. One Notting Hill doctor, for example, diagnosed a widespread "Caribbean syndrome" consisting of "apathy and an inability to exercise initiative," and sociologist Sheila Patterson identified "slowness, laziness unless under firm supervision, irresponsibility and a disinclination to regard hard work as creditable in itself or the job as more than a source of wages" as widespread among the whole West Indian population. ${ }^{22}$ According to this view, West Indians

\footnotetext{
nance Factory, 3 January 1942, Public Record Office (PRO) LAB 26/53; Allan Wilmot in The Windrush Legacy, p. 4. For West Indian men's involvement in the war effort, see also A. R. Watson, West Indian Workers in Britain (London, 1942); Oliver Marshall, ed., The Caribbean at War: "British West Indians" in World War Two (London, 1992); and Marika Sherwood, Many Struggles: West Indian Workers and Service Personnel in Britain, 1939-45 (London, 1985).

${ }^{21}$ Baron Baker in The Windrush Legacy, 17; Euton Christian cited in Phillips and Phillips, Windrush, p. 51; Learie Constantine to Manchester Regional Controller, 27 June 1945, PRO LAB 26/134.

${ }^{22}$ Unnamed doctor cited in James Wickenden, Colour in Britain (London, 1958), p. 28; Sheila Patterson, Dark Strangers (London, 1963), p. 81.
} 
were at best "plodding and persistent," at worst simply parasitic and intent on "living on National Assistance or the immoral earnings of white women." 23

Yet the competitive threat posed by West Indian men to white workers anxious to maintain the high wages and restrictive practices possible under conditions of full employment gave rise to a charge never heard in the colonies: that West Indians worked not too little but too much. A BBC publication entitled Going to Britain? advised West Indians not to risk "Overdoing It," by which it meant working through tea-breaks and hogging overtime. Such white commentators viewed ambition among West Indian men as an obstreperous "individualism" which, if taken to extremes, could even turn psychotic. ${ }^{24}$ West Indian men were also considered poor workmates. Though encouraging them to become "one of the boys" on the factory floor, white colleagues were heard to complain that they proved quite the opposite: "Often [the West Indian worker] doesn't smoke, he doesn't stand his round of drinks in the pub after work, he may work too hard, he doesn't know or learn the factory gossip or protocol of behaviour or accepted forms of swearing." It was this failure to fit in when combined with their alleged laziness and overambition which, according to a 1960s survey of employers, prevented West Indians from getting jobs better than those of other immigrants possessing inferior qualifications. ${ }^{25}$

The work ethic of West Indian men differed markedly from white perceptions of it. The workshyness considered so rife by white commentators was thought by West Indians to exist only in an unrespectable minority. These were the "hustlers" described by West Indian sociologists Stuart Hall and Ken Pryce, those denizens of an underground " "colony' culture" whose "conception of manhood and masculinity" was injured by menial work and its overtones of slavery. The temptations of welfare and the gray market being so great, and the rewards of regular employment so meager, hustlers sought autonomy and self-respect through spurning the "shit work" on offer in Britain. From this perspec-

${ }^{23}$ Joyce Eggington, They Seek a Living (London, 1957), p. 86; David Maxwell Fyfe cited in Gilroy, There Ain't No Black in the Union Jack, p. 79.

${ }^{24}$ British Broadcasting Corporation (BBC) Caribbean Service, Going to Britain? Talks Addressed to West Indians (London, 1959), p. 66; Michael Banton, The Coloured Quarter: Negro Immigration in an English City (London, 1955), p. 204. The psychotic potential of ambition was identified in the correlation between "goal-striving" and the high incidence of schizophrenia among West Indians, which ran at two and a half times the rate among men than among women. See Christopher Bagley, "Schizophrenia in Immigrant Groups," Race Today 1 (1969): 170-74.

${ }^{25}$ BBC Caribbean Service, Going to Britain? p. 58; unnamed "high trade unionist," cited in Patterson, Dark Strangers, p. 150; Peter L. Wright, The Coloured Worker in British Industry (London, 1968), p. 214. 
tive, their aversion to a nine-to-five existence was not so much the cause as the effect of poor employment opportunities. ${ }^{26}$

Respectable West Indian men were at pains to dissociate themselves from such "parasites [who] muddy the water for the boys" by refusing employment and drawing the dole. While mendicancy smacked of a colonial dependency under which "everything was being done for us," financial independence was considered a matter of racial pride: hence community activist Neville Maxwell's promotion of his "Operation Bootstrap" as a Smilesian initiative in self-help. ${ }^{27}$ The charge of laziness was contradicted in the minds of many West Indian men by the very fact of their migration. Hard work had paid for their fares to get to Britain, and hard work for good pay was what they hoped to find once they arrived. Moreover, having escaped a stagnant colonial society that perverted drive into funk and talent into "futility," men like Vida Naipaul were determined to prove their worth in the metropole. Such men were every bit as ambitious as some whites feared. ${ }^{28}$

If all they wanted were better wages, migration paid off for West Indian men. Migrants such as carpenter Wallace Collins grew "proud and strong"' through the performance of steady work and earned money in a manner that could not be imagined in their impoverished homeland, where "owning a home was out of their welkin, a car ... [an] impossibility." The problem was that, in return, the majority underwent a process of proletarianization aptly described by historian Ron Ramdin as "The Making of the Black Working Class." Upon arrival, less than a quarter of the West Indian men polled by sociologist Ruth Glass considered themselves to be semi- or unskilled. Yet over three-fifths of the men were placed in such jobs in Britain, with fully half of them consigned to the lowest category. Of the male sample as a whole, only 5 percent had gained a better status job as immigrants, compared to 54 percent who had taken one of lower standing: "Men who were employers in Port of Spain have become factory hands in London." 29

${ }^{26}$ Hall et al., Policing the Crisis, p. 349; Ken Pryce, Endless Pressure: A Study of West Indian Life-Styles in Bristol, rev. ed. (Bristol, 1986), p. 56. Pryce's fieldwork was conducted from 1969 to 1974.

${ }^{27}$ Samuel Selvon, The Lonely Londoners (London, 1956), p. 32; Interview with Rene Webb, IWM Sound Archive, SR 15285; Neville Maxwell, The Power of Negro Action (London, 1965), p. 37.

${ }^{28}$ V. S. Naipaul, The Middle Passage (London, 1962), p. 42.

${ }^{29}$ Collins, Jamaican Migrant, p. 105; Ron Ramdin, The Making of the Black Working Class in Britain (Aldershot, 1987); Ruth Glass, Newcomers: The West Indians in London (London, 1960), pp. 29-31. For the employment of West Indian immigrants in Britain, see also Alistair Hennessy, "Workers of the Night: West Indians in Britain," and Malcolm Cross and Mark Johnson, "Mobility Denied: Afro-Caribbean Labour and the British Economy," both in Lost Illusions: Caribbean Minorities in Britain and the Netherlands, 
One reason for deskilling lay in the disparity between the West Indian and British economies. Men found that their ability to be jacks-ofall-trades, invaluable under conditions of underemployment in the agrarian and artisanal Caribbean, was worthless when transferred to industrial Britain. There was also the question of certification, as engineer Ainsley Grant found to his cost when he could not prove his credentials and was instead given "a bucket, a broom and a shovel and showed . . . where to start sweeping." But in truth the question of skill was an irrelevance to most employers, who purposely took on men like Frank King in order to fill positions considered beneath the dignity of white males: "When I was demobbed in 1949 .. . I was offered a labouring job. I was a qualified engineer. It did not matter what your qualification was, there was always the labouring job, reserved for you once they saw that you were coloured." 30 More humiliating still, West Indian men found themselves expected to display a "courteous subservience and contentment with a lowly state of menial employment" out of gratitude to their white taskmasters. It was these indignities which explained why the Jamaican men interviewed by Nancy Foner in the 1970s felt that the higher wages they had achieved in Britain could not compensate for the discrimination that they had endured. ${ }^{31}$

West Indian men were damned if they worked and damned if they didn't. They were made deskilled and then considered unskilled. They were accused of sloth and warned against ambition. The variety of criticisms directed against them reduced some to exasperation. "How can we be taking all the jobs, and at the same time be living on National Assistance?' one West Indian teenager asked his white friends. But so wide was the gap between white and West Indian perceptions of the matter that he could expect no sensible answer. ${ }^{32}$

\section{Family Life}

In family matters, as in work, West Indian men arrived in Britain with a reputation for irresponsibility which white observers believed

ed. Malcolm Cross and Hans Entzinger (London, 1988); and Clive Harris, "Postwar Migration and the Industrial Reserve Army," in Inside Babylon: The Caribbean Diaspora in Britain, ed. Winston James and Clive Harris (London, 1993).

${ }^{30}$ Clarence Senior and Douglas Manley, A Report on Jamaican Migration to Great Britain (Kingston, 1955), p. 42; Ainsley Grant and Frank King cited in Hinds, Journey to an Illusion, p. 65.

${ }^{31}$ Braithwaite, To Sir, with Love, p. 39; Nancy Foner, Jamaica Farewell: Jamaican Migrants in London (London, 1979), pp. 109-15.

${ }^{32}$ Unnamed West Indian youth club member cited in Hinds, Journey to an Illusion, p. 113. 
could only be remedied through their approximation to an indigenous norm. The norm in question was companionship, that "joint concern [by spouses] for the welfare of their children and a continuing share in each other's affairs" so strenuously promoted by social scientists and liberal Christians during the mid-twentieth century. ${ }^{33}$ White writers opined that West Indian men could become regular wage earners in Britain, making marriage affordable for all and allowing "more and more" of them to assume the "normal British role and responsibilities of the father of the family." West Indian women, meanwhile, stood to learn from their white sisters that "English wives do not allow their husbands to dominate the home, but that they expect at least to be equal partners." With men assuming family responsibilities and their womenfolk demanding equality, some commentators dared to hope that West Indian marriages were becoming not only more numerous but also "more egalitarian and less patricental" in Britain than had been the case in the colonial West Indies. ${ }^{34}$

Yet, whereas social scientists spoke of companionship "becoming universal" among the generality of the British population, those studying West Indians tended to find it a minority affair at best. E. J. Rose and Sheila Patterson distinguished between "two basic classes" of West Indian immigrants: an essentially middle-class group striving for assimilation and a residuum untouched by the "Anglo-American ideal of love and marriage." 35 Worse still, Patterson believed that immigration jeopardized what little stability had hitherto existed within West Indian family life. Mothers found themselves without kin support, while fathers who appeared alien and uneducated to their British-born offspring had become more marginal than ever to home life. Unless the state refused to be a surrogate parent and compelled fathers to take responsibility for their offspring, Patterson predicted the total breakdown of the black family, foreshadowing the Moynihan report in her vision of welfare mothers haplessly raising a generation of wayward youths without male support. ${ }^{36}$

${ }^{33}$ Gertrude Williams, The Economics of Everyday Life in the West Indies (Kingston, 1953), pp. 49-50. For the centrality of companionship in mid-twentieth-century models of British masculinity, see Marcus Collins, "Good Companions: Personal Relationships between Men and Women in Twentieth Century Britain" (Ph.D. diss., Columbia University, 2000), chap. 4.

${ }^{34}$ E. J. B. Rose, Colour and Citizenship: A Report on British Race Relations (London, 1969), p. 432; Clifford S. Hill, Black and White in Harmony: The Drama of West Indians in the Big City from a London Minister's Notebook (London, 1958), p. 77; Sheila Patterson in Immigrants in London, ed. Sheila Patterson (London, 1963), p. 10.

${ }^{35}$ Ronald Fletcher, The Family and Marriage in Britain (Harmondsworth, 1966), p. 231; Rose, Colour and Citizenship, p. 431; Patterson, Dark Strangers, p. 337.

${ }^{36}$ Patterson in Immigrants in London, p. 10; Dark Strangers, p. 344. For a comparison of the Moynihan Report and white sociological writing on the West Indian family, 
Far from underpinning companionship, women's emancipation was also seen by some white observers as destabilizing what were already dysfunctional families. Psychiatrist Ari Kiev diagnosed a "vicious circle of increasing conflict between the sexes" as men's reaction against wifely equality pushed wives to claim still greater independence. Social workers Juliet Cheetham and Albert Hyndman detected the same escalation of "mutual ambivalence and hostility" between the sexes due to the erosion of the "dominant patriarchal role." Badgered into marrying by their newly confident womenfolk and then prevented from exercising patriarchal authority due to their wives' independent earning capacity, West Indian men reportedly felt sorely treated by the " "oman country", in which they had settled. ${ }^{37}$

What West Indians said about family life only partly corresponded to white perceptions of it. They were generally willing to acknowledge that much was wrong with the family in the colonial Caribbean, with Orlando Patterson describing the "complete demoralisation of the Negro male" resulting from slavery and Fernando Henriques identifying a general societal "disnomia" insinuating itself into familial arrangements. ${ }^{38}$ They also accepted that some West Indian male migrants cut loose from family ties, ignoring their "very grave responsibilities to their women and their children" back home and leading lives of carefree bachelors once abroad. The joys of irresponsibility and male solidarity proved preferable to some men even after the arrival of West Indian women in large numbers during the late fifties and sixties. They chose the life of the "kickster," explained social worker Katrin Fitzherbert, their drinking, gambling, and desire to be "one of the boys" making them failures as fathers and husbands. ${ }^{39}$

But West Indian commentators denied that such behavior amounted

see Errol Lawrence, "In the Abundance of Water the Fool Is Thirsty: Sociology and Black 'Pathology,", in The Empire Strikes Back: Race and Racism in Seventies Britain, ed. Centre for Contemporary Cultural Studies (London, 1982), p. 116.

${ }^{37}$ Ari Kiev, "Psychiatric Illness among West Indians in London," Race 5 (1964): 53; Juliet Cheetham, Social Work with Immigrants (London, 1972), p. 131; Albert Hyndman, "The West Indian in London," in The West Indian Comes to England, ed. S. K. Ruck (London, 1960), pp. 126, 127.

${ }^{38}$ Orlando Patterson, The Sociology of Slavery (London, 1967), p. 167; Fernando Henriques, Family and Colour in Jamaica, rev. ed. (London, 1968), p. 171.

${ }^{39}$ Text of October 1956 broadcast by Ivo De Souza, PRO CO 1032/122; Katrin Fitzherbert, West Indian Children in London (London, 1967), pp. 38-39. It is perhaps significant in this respect that oral historian Mary Chamberlain finds that even those Barbadian men who migrated within networks of family connections nonetheless portrayed themselves as autonomous individuals rather than family men. Whereas women unfailingly placed their migratory experience within a family context, she argues, men stressed a sense of adventure and self-fulfillment. See Mary Chamberlain, Narratives of Exile and Return (Basingstoke, 1997), chaps. 3, 4. 
to an endemic antifamilialism among West Indian men. Black sociologists were more careful than their white counterparts to avoid using a British norm when describing the colonial West Indian family structure. Employing the language of cultural relativism, they argued that illegitimacy should not be mistaken for family instability, that West Indians' reluctance to marry indicated their high respect for the institution and that "Faithful Concubinage" was neither immoral nor patriarchal, nor necessarily detrimental to the well-being of the woman and her children. ${ }^{40}$ And, though generally circumspect about their family life in Britain, those West Indians who addressed the matter once again differentiated between a respectable majority and the dissolute few. The average Jamaican man regarded the family as his "pinnacle of morality," explained Wallace Collins, placing "his wife and kids . . a above his head like a guiding star." 41

It followed that, rather than resisting the companionship and emancipation of wives urged upon them by whites, most West Indian men were considered willing participants by black writers. It was only a "small proportion" of men who failed to "adjust to the new demands made on them," emphasized Fitzherbert, the larger number not merely marrying but participating wholeheartedly in a partnership of equals: "In the West Indies it is rare to see a man doing housework or minding children. In England most men help their wives with cooking and cleaning and take an active part in bringing up their children. They have a lot more responsibility but get their reward by being drawn as full members into their family's domestic life." Such was the case with Isaac Gordon, a wastrel and philanderer in Jamaica who made good in Britain. "When I come to this country I did very lonely," he explained, "and I very happy since I met my wife. We get married twelve years ago and have a family. I am very happy in my life." It was the overweening tendency of whites to overlook this mundane picture of domestic contentment in favor of sensationalistic visions of husbandly failure which led Collins to despair that "the English could not fathom the motivation of the Jamaican male." 42

\section{Interracial Sex}

"Negrophiles" or "negrophobes," white writers appeared to be obsessed by sexual relationships between black men and white women.

${ }^{40}$ Henriques, Family and Colour in Jamaica, pp. 164, 163, 92. See also Katrin Norris, Jamaica: The Search for an Identity (London, 1962), p. 13.

${ }^{41}$ Collins, Jamaican Migrant, p. 60.

${ }^{42}$ Fitzherbert, West Indian Children, p. 38; Isaac Gordon, Going Where the Work Is (London, 1979), p. 30; Collins, Jamaican Migrant, p. 60. 
Avowedly sympathetic observers such as Colin MacInnes did nothing to dispel the mystique of black male sexuality, reporting in 1956 that 'there seems much truth ... that every coloured man is longing to embrace a white woman." But though he had a taste for black rough trade, most of his compatriots responded with a febrile disgust identified by all commentators and opinion polls to be one of, perhaps the most, important elements of racism in Britain. ${ }^{43}$ As with previous sexual "Perils" occurring in Britain and its colonies-"Yellow," "Brown," and "Black"West Indian men were widely regarded by white observers to be predatory creatures who "kept [their] hunting instincts alive by stalking prey in human form and of the female gender.' Bedding white women reputedly conferred status on black men and served as a means of "paying back the white man for real or imagined slights in the past." West Indian men were also thought promiscuous, considering it "self-evident that men should have sexual freedom" and trailing venereal disease in their wake of their conquests. ${ }^{44}$ And, while miscegenation seemingly satisfied their "pathetic urge to lighten the strain," it muddied British blood, spawned unwanted mongrel children, and (in the words of one Colonial Office briefing paper) brought about an unspecified but detrimental "effect on the national way of life." 45

Opinions differed among whites on the women involved. To the more chivalrous of racists, they were innocents in "mortal danger" who, unless "Vigilante Patrols" were established for their protection, would be "enticed into becoming prostitutes and then intimidated into remaining so by Coloured men who live off them." But West Indian men forcibly deflowering the finest English roses was hardly the problem. Joyce Eggington noted that "the white men who campaign to 'Protect

${ }^{43}$ Colin MacInnes, "A Short Guide for Jumbles" (1956), in England, Half English, compiled by MacInnes (New York, 1961), p. 24. For polling evidence of the strength of white opposition to interracial relationships, see William A. Belson, The Impact of Television (London, 1967), pp. 103-4; Clifford S. Hill, How Colour Prejudiced Is Britain? (London, 1965), pp. 37-38; and Patterson, Dark Strangers, p. 281. For a controversial interpretation of the significance of black sexuality to British racism, see Anna Marie Smith, New Right Discourse on Race and Sexuality: Britain, 1968-1990 (Cambridge, 1994).

${ }^{44}$ O. R. Dathorne, Dumplings in the Soup (London, 1963), p. 92; Wickenden, Colour in Britain, p. 20; Geoffrey Gorer, Sex and Marriage in England Today (London, 1971), p. 43. For fears about black men's designs on white women in the colonies, see Ann Laura Stoler, "Carnal Knowledge and Imperial Power: Gender, Race and Morality in Colonial Asia," in Feminism and History, ed. Joan Wallach Scott (Oxford, 1996), p. 228; and Margaret Strobel, European Women and the Second British Empire (Bloomington, Ind., 1991), pp. 5-6.

${ }^{45}$ Gorer, Sex and Marriage in England Today, p. 43; Eggington, They Seek a Living, p. 114; Briefing paper for Lord Lloyd, February 1956, PRO CO 1032/121. 
our women' are often referring to the type of women they would least care to protect." 46 White women attracted to black men had to be misfits, commentators claimed: whether gold diggers bent on taking West Indians for a ride, perverts seeking "pleasure from physical punishment" or inadequates suffering from an "inferior economic position and low earning power ... emotional insecurity and a background of personal rejection." Scapegoating certainly lay behind some of this vilification. Chris Waters and Sonya Rose describe how white women who engaged in interracial sex in mid-twentieth-century Britain were ritually expelled from mainstream society in order to maintain a cohesive model of national identity. Yet, insofar as this stigmatization was effective, it became a self-fulfilling prophesy, as only women indifferent to or without a reputation to maintain would dare date men of a different race. ${ }^{47}$

Such attitudes elicited diverse reactions from West Indian men. The more respectable the man, the more concerned he was to disown his countrymen's reputation for having an "abnormal and excessive" sexual appetite. "What can I do," asked Jamaican Dick Pixley, "to show that this belief of black sexual potency is just not true?"' Various methods of rebuttal were used. Some turned to science. Learie Constantine cited the work of "eugenics investigators" to prove that any greater sexual activity among black people was due to a paucity of "alternative entertainments." ${ }^{48}$ Some drew upon personal experience, with memoirists generally undercutting the stereotype by adopting a reticent, almost prudish tone when discussing their relationships. Hence Alfred Williams confessed that he "never love no woman or girl from eighteen up to thirty," having long been clueless about what love was, let alone how to get it, and fellow Jamaican E. M. Noble recalled nothing more salacious about his courting

${ }^{46}$ Peter Griffiths and Donald Finney cited in Paul Foot, Immigration and Race in British Politics (Harmondsworth, 1965), pp. 45, 43; Colin Jordan, The Coloured Invasion (London, c. 1966), n.p.; Eggington, They Seek a Living, p. 114.

${ }^{47}$ Report from the Chief Constable of Sheffield, 3 October 1952, PRO CO 1028/25; Michael Banton, White and Coloured: The Behaviour of British People towards Coloured Immigrants (London, 1959), p. 128, and The Coloured Quarter, p. 152; Chris Waters, "'Dark Strangers in Our Midst': Discourses of Race and Nation in Britain, 1947-63,"' Journal of British Studies 36 (1997): 230; Sonya O. Rose, "Sex, Citizenship and the Nation in World War II Britain," American Historical Review 103 (1998): 1158. For evidence of respectable white women shunning all contact with West Indian men, see Eggington, They Seek a Living, p. 85; Wright, The Coloured Worker, pp. 60-61; W. W. Daniel, Racial Discrimination in England (Harmondsworth, 1968), p. 118; and Kenneth Ramchand, "The Colour Problem at the University: A West Indian's Changing Attitudes," in Disappointed Guests: Essays by African, Asian and West Indian Students, ed. Henri Tajfel and John L. Dawson (London, 1965), p. 34.

${ }^{48}$ Constantine, Colour Bar, p. 89; Dick Pixley, The Closed Question: Race Relations in Britain Today (London, 1968), p. 111; Constantine, Colour Bar, p. 90. 
days than a few chaste encounters with a white girl, chaperoned by his aunt. ${ }^{49}$ Some even sought to turn the tables by suggesting that it was not West Indians but whites who were deviant on account of their "sexual jealousy" of black people and "tribal tabu" against miscegenation. ${ }^{50}$

Yet even those who, like Jamaican Wallace Collins and Trinidadian Earl Lewis, did their best to play down West Indian men's lascivious reputation were forced to concede that many of their compatriots were doing their best to live up to it. "Migrant Jamaican men are polygamous to say the least," explained Collins, "in fact they are 'wild,' for their monumental faith in their virility would incite them to move any mountain just to raise a skirt and claim its contents." ${ }^{51}$ White women, moreover, had all the allure of forbidden fruit. Sam Selvon's The Lonely Londoners (1956) recounted his characters' delight at the "bags of white pussy" available in Britain, causing men like his protagonist Moses to bed countless white women and shun black women altogether ("a spade wouldn't hit a spade when it have so much other talent on parade"). For his part, The Mighty Terror, not content with being adored by "all the girls" in London, aspired to marry a "woman as white as snow" and father a "nice blue-eyed baby" as confirmation of his acculturation. ${ }^{52}$

Experiences of interracial relationships varied considerably. Some men got just what they wanted. Ken Pryce was repeatedly told by residents of a Jamaican ghetto in Bristol that 'if it weren't for the sympathy and generosity of English women in their relations with black men, black men would find it virtually impossible to survive in England." It was such women's sexual adventurousness as much as their welcoming nature that pleased their partners, with one of Pryce's informants thrilled by their "kinky" technique and a character in George Lamming's The Emigrants (1954) enthusing that white women would perform sexual acts "no decent girl from home would ever dream of." These men had no complaints about the sort of woman willing to consort with them and regarded any aspersions on their character as a matter of unadulterated prejudice. As one man commented, "If I was seen walking down Lime

${ }^{49}$ Alfred Williams and Ray Brown, To Live It Is to Know It (Castleford, 1987), p. 31; Noble, Jamaican Airman, p. 48.

${ }^{50}$ Fernando Henriques, Children of Caliban: Miscegenation (London, 1974), p. 143; Constantine, Colour Bar, p. 92. For a fictional account of one West Indian man's encounters with deviant white sexuality, see Andrew Salkey, Escape to an Autumn Pavement (London, 1960).

${ }^{51}$ E. R. Lewis, The Whites and the Coloureds (London, 1963), p. 7; Collins, Jamaican Migrant, p. 60.

${ }_{52}$ Selvon, The Lonely Londoners, pp. 100, 123; The Mighty Terror cited in Rohlehr, Calypso and Society, p. 519, and Rohlehr, "Heading North,"'Kings of Calypso (MAT compact disk 244). 
Street with the Queen of England and nobody recognised who she was, it would be assumed that she was a street girl.",53

Other West Indian men were far less enamored with the women available to them. With "nice girls" commonly refusing to dance or even share offices with black men and otherwise willing women being forced to break off engagements at their parents' behest, the remainder appeared to Trinidadian student Kenneth Ramchand to be so many castoffs: "A tribe of nurses, au pair girls, typists, shop assistants, one or two divorcees, a few erring wives, a nymphomaniac and various rejected university girls." Writers also expressed concerns about the motives of the women concerned, Sam Selvon contending that "the cruder you are the more they like you" and Rhodes scholar Mervyn Morris protesting that he was treated "not as a man but as a foreign phallus." Under these terms, sexual relationships with white women were less a mark of acceptance than another, subtler form of racial stigma. ${ }^{54}$

Adverse experiences dovetailed with an increasing intellectual opposition to exogamy among West Indian men. An early indication of changing attitudes came in a series of calypsos composed by Atilla in Trinidad during the late 1940s and early $1950 \mathrm{~s}$, in which he described a partiality for white women as "nothing but real discrimination" and portrayed erstwhile nationalist hero Uriah Butler's marriage to a British woman as equivalent to Samson's capitulation to Delilah. ${ }^{55}$ Though this seems to have been a minority opinion at the time, the burgeoning influence of American and Francophone African theorists of negritude in the 1960s convinced some West Indian men that their preference for white women was a symptom of self-loathing. In the mid-sixties, Morris was suggesting that West Indian men's motives in pursuing white women were no more honorable than the reverse, and Maxwell identified the intermarrying type as suffering from a lack of pride in himself, his family, and his race. By the early seventies, even an old libertine like Sam Selvon's Moses had been converted to the cause: "The tide is turning, yes sir. . . . Whereas it used to be the top of the social ladder to be seen escorting a white piece in the Dilly or the Circus, brothers are scorning that sort of thing nowadays. ... I have come to my senses and realize

${ }^{53}$ Pryce, Endless Pressure, p. 84; Iron-Leg cited Pryce, Endless Pressure, p. 49; George Lamming, The Emigrants (London, 1980), p. 147; unnamed man cited in Richmond, Colour Prejudice in Britain, p. 78.

${ }^{54}$ Kenneth Ramchand in Disappointed Guests, p. 32; Selvon, The Lonely Londoners, p. 124; Mervyn Morris in Disappointed Guests, p. 19. For accounts of white parents seeking to end their daughters' relationships with West Indian men, see Braithwaite, To Sir, with Love, pp. 169-73; and Michael Abdul Malik, From Michael de Freitas to Michael $X$ (London, 1968), pp. 135-38.

${ }^{55}$ Quevedo, Atilla's Kaiso, pp. 126, 130, 137-38. 
that black pussy is just as sweet as the white one, if not sweeter, and henceforth I shall only hit a white stroke for variety.' Some West Indian men, albeit via a contrasting route, began to share with whites the belief that interracial sex damaged community cohesion. ${ }^{56}$

\section{Interracial Violence}

Most white writers believed West Indian men to be aggressive by inclination, almost by nature, their short fuses primed for ignition at the slightest provocation. Compounding their fears was the belief that West Indians' notorious "touchy or 'chip on the shoulder' attitude," though formed in the Caribbean, would if anything escalate upon their arrival in Britain in reaction to discrimination, imagined or real. Such views formed the basis for social psychologist Anthony Richmond's taxonomy of West Indian male immigrants, in which aggression served as the key indicator of acculturation. The ideal immigrant in Richmond's eyes was the "balanced personality" who refused to succumb to his aggressive inclinations in response to ill-treatment by whites. Less desirable were those West Indian men who either suppressed or sublimated their aggression: the former adopting a saintly demeanor at the expense of their sanity, the latter channeling their aggression into black activism. But what most concerned Richmond was the "overtly aggressive" type who hit back against perceived prejudice by attacking anyone (preferably, but not necessarily, white) unlucky enough to cross his path. ${ }^{57}$

Whereas West Indian men's sexuality was considered by white commentators to bring out the worst in white women, their bellicosity was thought to elicit the very basest behavior from white men. According to psychoanalysts, prejudice originated in a projection of "parricide or other aggressive trends" and, according to out-group theorists, it found expression in a struggle with blacks for scarce resources. "Violence and the danger of violence and hostility will always be present," warned sociologist James Wickenden, "where a concentration of immigrants has formed too quickly for an area's capacity to absorb them." Wickenden accordingly attributed the 1958 race riots to the manner in which white and West Indian men erupted on contact as if in some spontaneous chem-

${ }^{56}$ Mervyn Morris, "Feeling, Affection, Respect," in Disappointed Guests, p. 19; Maxwell, The Power of Negro Action, p. 27; Sam Selvon, Moses Ascending (London, 1975), pp. 22-23. For opposition to interracial sex within the international black consciousness movement, see Frantz Fanon, Black Skin, White Masks (London, 1986), p. 16; Eldridge Cleaver, Soul on Ice (London, 1970), p. 22; and Samuel Bonhomme, Enoch Powell and the West Indian Immigrants (Harrow Weald, 1971), p. 40.

${ }^{57}$ Patterson, Dark Strangers, p. 81; Richmond, Colour Prejudice, pp. 117-21. 
ical reaction. Notting Hill he blamed on Teddy Boys clashing with West Indian men exhibiting similarly criminal and offensive behavior, while Nottingham was triggered in his view by West Indian "wide boys," whose off-hand manner, aggressive behavior, flashy clothes, and flashing knives incited white wrath. ${ }^{58}$

West Indian men were on the whole baffled by their reputation for being firebrands set upon violent confrontation. They bristled at whites customarily "expect[ing] [them] to be aggressive" and rebutted allegations of intemperance by drawing attention to the "great reserves of courage and self-restraint" they displayed in refusing to rise to the racist bait. "No black person will willfully set out to hurt a white person," insisted Trinidadian writer Samuel Bonhomme, "unless he is provoked beyond all reasonable doubt." ${ }^{59}$ From this perspective, Notting Hill was less confirmation of West Indian men's combativeness than a clear case of self-defense. Teds, fascists, and assorted ne'er-do-wells had been persecuting West Indians in the area for years and the immediate trigger to the riots (as in Nottingham) had been the usual white fury over one of "their" women consorting with a black man. "Bullied by prejudice, hunted by violent men" and having endured three days of sustained attacks during which the police had not only failed to defend them but instructed them not to defend themselves, West Indian men justified their decision to fight back as a defensive imperative and as a matter of communal pride. "We had to put our foot down," remembered community leader Baron Baker, "Our homes were being attacked, our women folks were being attacked, and we weren't the ones going out onto the street looking for trouble. ... We really had to fight back, which we did." By likening Notting Hill's West Indian community to "the gentlest creature ... [having to] abandon its nature in order to protect its spirit from either destruction or disgrace," George Lamming spoke in defense of immigrants who had not instigated but reluctantly responded to violence. Just as they rejected white stereotypes of them as lazy workers, negligent fathers, and rapacious lovers, so too did West Indian men refuse to live up to their reputation as born fighters-until, that is, the advent of Black Power. ${ }^{60}$

${ }^{58}$ H. V. Dicks, “Psychological Factors in Prejudice,'” Race 1 (1959): 31; Wickenden, Colour in Britain, pp. 44, 25.

${ }^{59}$ Collins, Jamaican Migrant, p. 64; Lewis, The Whites and the Coloureds, p. 8; Bonhomme, Enoch Powell, p. 37. For an excellent account of the Notting Hill riots, see Pilkington, Beyond the Mother Country.

${ }^{60}$ Merrill Ferguson in Alienation, ed. Timothy O'Keefe (London, 1960), p. 155; Baron Baker cited in Pilkington, Beyond the Mother Country, p. 121; Lamming, The Pleasures of Exile, p. 79. 


\section{Citizenship}

The paradox underlying prevailing white attitudes to West Indian men was that they were characterized as essentially unassimilable deviants while at the same time being expected to assimilate to white gender norms. As employees, they were encouraged to slot into the "roles of industrial worker" through displaying a "steady" commitment to their jobs and "los[ing] their chip on the shoulder attitude" toward discrimination. ${ }^{61}$ As family men, they would demonstrate their "accommodation" to British conventions by "marrying sooner, and taking a more permanent interest in their children's security and education." As lovers, they were expected to respect "local mores with regard to women met in the street" by making sure not to "frequent night clubs and associate with loose women." ${ }^{62}$ And as potential fighters, they were urged to curb their "assertion and personal aggressiveness" in the name of adaptation. Within the functionalist and homogenous model of British national identity described by Chris Waters, West Indian men either embraced Britishness or else were considered to be antagonistic to all it stood for ${ }^{63}$

Yet, ironically enough, West Indian men both wished and believed themselves to be less British when in Britain than in the colonial Caribbean. In the West Indies, after all, they had acted "more British than the British" and had accorded the British gentleman, whom they imagined to be the archetype of British masculinity, a genuine if grudging respect. But migration to Britain soon disabused them of the notion that all white men were gentlemen. They expected to encounter legions of "bowler hats and ... tightly rolled-up umbrellas," but the sight of white men performing menial work tore through their assumptions. ${ }^{64}$ Roy Sawh was so thrown by the spectacle of white railway porters upon arriving at Victoria station that he asked a policeman whether he was really in London, while Sam Selvon found the same situation to be an instant fillip to his self-esteem: "Well yuh could imagine. Ah feeling like ah lord. Me chest swell. Ah only seeing wite man carrying grip and luggage all over the place. So this fella who come by me, he say, 'Let me take your luggage

${ }^{61}$ Richmond, Colour Prejudice, p. 118; unnamed "liberal" trade unionist cited in Patterson, Dark Strangers, p. 150.

${ }_{62}$ Patterson, Dark Strangers, p. 17; unnamed white shop assistant cited in Lewis, The Whites and the Coloureds, p. 5.

${ }^{63}$ Banton, The Coloured Quarter, p. 204; Waters, " 'Dark Strangers in Our Midst."," For the perceived difficulties of assimilating black immigrants, see also Kathleen Paul, "From Subjects to Immigrants: Black Britons and National Identity, 1948-62," in The Right to Belong: Citizenship and National Identity in Britain, 1930-1960, ed. Richard Weight and Abigail Beach (London, 1998).

${ }^{64}$ Randolph Beresford in The Caribbean at War, p. 3; Ken cited in Hinds, Journey to an Illusion, p. 15. 
for you, sir' and all this time he tipping he hat and making me feel as if $I$ is a star or something." ${ }^{65}$ Familiarity with ordinary British men often bred contempt. A man who appeared to George Lamming to be a true British gent, "bowler hat and the lot," turned out to be a raving bigot. William Strachan's encounters with British servicemen in World War II "destroyed all [his] ... ideals," for they were incredulous at his decision to volunteer when they would "do anything to get away from the bloody war." 66 The same woeful lack of ambition was detected by a number of West Indian men in work colleagues who resented how the "keen competition and hard work" of West Indians "show[ed] up the indolence and idleness of a sizable proportion of British workers." Whereas these West Indians were eager to succeed, many of their white counterparts appeared bovinely content with their lot "as long as their football team plays on Saturday and they can get beer in the pub.,"67

West Indians' admiration for the gentlemanly ideal also declined in tandem with the prestige of Britain in the postwar period, with Neville Maxwell drawing upon modish anti-Establishment rhetoric for his excoriation of Britain's "Profumo-Keeler values . . grouse-moor mentalities ... [and] stiff-upper-lipped manners and mannerisms." The theme was most famously explored in C. L. R. James's Beyond a Boundary (1963), which described how British gentlemanliness, as epitomized by its cricketers, had slid from an Edwardian "Golden Age" of dynamism and fair play through its abandonment of "chivalry" in body line to its subsequent anemic state. The reputation for gentlemanly daring had passed from Britain to the West Indies, he maintained: "Thomas Arnold, Thomas Hughes and the Old Master himself [W. G. Grace] would have recognized Frank Worrell as their boy." A New World masculinity had been called into being to restore the balance of the Old. ${ }^{68}$

But if James concurred with earlier nationalist leaders in wishing to claim gentlemanly virtue on behalf of West Indians, a younger generation of West Indian writers confessed themselves eager to disown gentlemanliness altogether. Barbadians, whose strong work ethic and civilized bearing acquired them a reputation for "Englishness" among fellow

${ }^{65}$ Lionel Robinson, "Roy Sawh: A Profile," in Roy Sawh, From Where I Stand (London, 1987), p. 25; Selvon, "Finding Piccadilly Circus" (1950), in Foreday Morning: Selected Prose, 1946-86 (London, 1989), p. 123.

${ }^{66}$ Lamming, The Pleasures of Exile, pp. 89-90; interview with William Strachan, IWM Sound Archive, 10042/5, reel 2.

${ }^{67}$ Bonhomme, Enoch Powell, p. 23; Noble, Jamaican Airman, p. 66; Sam King cited in John Western, A Passage to England: Barbadian Londoners Speak of Home (London, 1992), p. 140.

${ }^{68}$ Maxwell, The Power of Negro Action, p. 13; James, Beyond a Boundary, pp. 209, 189, 252. 
West Indians, were criticized by their less Anglicized compatriots for displaying "decadent . . . virtues," while Jamaicans conversely attracted admiration from younger West Indians for their reputedly assertive demeanor ${ }^{69}$ Individual West Indians who affected gentlemanly manners found themselves accused by the likes of Lamming and Selvon of "playing the ass": "Harris is a fellar who like to play ladeda, and he like English customs and thing, he does be polite and say thank you and he does get up in the bus and the tube to let woman sit down, which is a thing even them Englishmen don't do ... bowler and umbrella, and brief case, with the Times fold up in the pocket so the name would show, and he walking upright like if is he alone who alive in the world. Only one thing, Harris face black." Such behavior won West Indian men no favors from whites, claimed Neville Maxwell, since they greeted "the sight of a black man posing in bowler hat and rolled umbrella" with uniformly "hostile stare[s]." Craven imitation, he declared, was "as sickening to [the average Englishman] as it would be nauseating to us.", 70

The idea that integration turned a West Indian into a "pitiful blackwhite man" found an echo in some autobiographical accounts. Jamaican Wallace Collins sought "the white man's . . . daughter's hand in marriage ... [and] promotion in his factory" before he came to appreciate that success on these terms involved having to "arrest [his] individualism, work within the confines of the myth they perpetuated about West Indians, and become a black senseless robot." And Trinidadian Ken, though he had started off "mak[ing] a great effort to be English," eventually had to abandon his belief that "decent, mild-mannered and respectable" West Indians like himself would be accepted into white society." Embracing blackness resolved the identity crisis engendered by assimilationism for both men. Collins decided to "quit" white society and marry a West Indian woman, and he came to accept the hedonism of his compatriots for displaying an integrity and independence lacking in conformity to white mores. For his part, Ken found that, whereas his vainglorious attempts to be British had involved the "complete negation of myself," a new black identity brought him true contentment: "I am no longer troubled about the rigmarole of acceptance and rejection. . . I I am indeed

${ }^{69}$ John Hearne, "What the Barbadian Means to Me," in Caribbean Essays: An Anthology, ed. Andrew Salkey (London, 1973), p. 20. For a comparison between Barbadian and Jamaican masculinity, see Lamming, The Pleasures of Exile, pp. 216-17.

${ }^{70}$ Lamming, The Pleasures of Exile, p. 55; Selvon, The Lonely Londoners, p. 128; Maxwell, The Power of Negro Action, pp. 8, 7.

${ }^{71}$ Bonhomme, Enoch Powell, p. 16; Collins, Jamaican Migrant, pp. 98, 75-76; Ken cited in Hinds, Journey to an Illusion, p. 4. 
grateful to the English. Grateful for rejecting me in order to discover myself. . . . I am a free man! An individual!" 72

It was men like these who were to provide a constituency for the Black Power movement of the late 1960s and early 1970s, which represented the most radical attempt yet to junk assimilationism and rethink the nature of black masculinity. Its acknowledged leader in Britain, Michael X., spoke for the whole movement when challenging every aspect of white prejudice against West Indian men. Renouncing his former habit of pimping and sponging off white girlfriends, he declared dependence on whites to be one of the "awful traps black men fell into" and extolled the virtues of hard work and self-help. He was penitent about his husbandly failings and paraded his New Man credentials when suggesting that men should help their partners with housework. He was also eager to scotch the myth of a superior West Indian virility, denying that he was the promiscuous type and recalling the anxiety amounting to "torture" he had experienced over sex upon getting married. And, reversing the notion that West Indian men preyed upon white women, he claimed that "desperate"' lady philanthropists were descending upon Notting Hill out of "sheer sexual need." 73

But the attempt by West Indian Black Power activists to advance a strictly black code of masculinity was undermined in two major respects. They, like a previous generation of nationalists in the colonial West Indies, still looked largely to gentlemanliness for their masculine ideals. Thus Stokely Carmichael adopted a tone of almost archaic gallantry when reminding the 1967 Dialectics of Liberation conference in London of Claude McKay's call to "face the murderous, cowardly pack / Pressed to the wall, dying, but fighting back!' Such chivalry extended to their treatment of West Indian women, with Michael X. vowing to kill any white man "laying hands on a black woman" and fellow Racial Adjustment Action Society leader Roy Sawh assuming the role of knightprotector toward his "beautiful black sisters" against their depredations at the hands of "female members of the master race." though they were determined to convince their own community of the pp. 2,5 .

${ }^{72}$ Collins, Jamaican Migrant, pp. 98, 97; Ken cited in Hinds, Journey to an Illusion,

${ }^{73}$ Malik, From Michael de Freitas to Michael X, pp. 160, 199, 120, 46, 79-80. For Michael X., see Derek Humphry and David Tindall, False Messiah: The Story of Michael $X$ (London, 1977). For Black Power and masculinity in the United States, see Michele Wallace, Black Macho and the Myth of the Superwoman (London, 1990).

${ }^{74}$ Claude McKay cited in Stokely Carmichael, Stokely Speaks (New York, 1971), p. 95; Michael X. cited in Humphry and Tindall, False Messiah, p. 64; Roy Sawh, "Black Power in Britain," in Justice First, ed. Lewis Donnelly (London, 1969), pp. 136-37. 
virtues of "being men and being responsible," they soon discovered that attention from whites was gained through reinforcing rather than refuting existing negative stereotypes of West Indian men. "If [the white man] insists on calling me a savage," Sawh warned, "I might be persuaded to show him how a real savage behaves." This wish simultaneously to present a respectable front to fellow West Indians and an intimidating one to whites induced ambivalent attitudes to violence, with activists like Sawh denouncing white fears as evidence of prejudice in one breath and doing their best to exacerbate them in another: "You used to turn your cheek when the white man hit you . . stop turning . . . hit him back.,"75

Though small in numbers and short-lived in influence, the Black Power movement exemplified the dilemmas facing West Indian men in trying to create a masculinity to call their own. Could West Indians appropriate white ideals without compromising their black identity? Could they place a positive value on aspects of the white stereotype of them without simply confirming every prejudice held against them? And, given the American origins of Black Power, could West Indian identity remain distinct from that of African-Americans once its British elements were excised? These were the questions which, having been posed so forcefully by Black Power, promised to shape the development of West Indian masculinity over the coming thirty years.

\section{Conclusion}

Masculinity mattered in mid-century race relations in that assimilationism foundered in large part upon the incompatibility of white and black conceptions of West Indian men. Assimilation required two willing parties, not one. West Indians' willingness to change had to be matched by whites' willingness to countenance that change was possible and to provide opportunities for it to happen. Yet we have seen how the same tired stereotypes of West Indian masculinity were repeated ad nauseam in justification of discriminatory attitudes and practices. In considering West Indian men to be beyond the pale and in refusing them good jobs and white wives, whites effectively prevented the assimilation that they professedly desired.

Though white observers did not hesitate to identity a largely spurious crisis of masculinity among West Indian men, their own conceptions

${ }^{75}$ Sawh, "Black Power in Britain" (ca. 1969), in From Where I Stand, p. 89; RAAS newsletter cited in Robinson, "Roy Sawh," p. 36. 
of masculinity did not betray that sense of anxiety so often depicted in historical accounts. ${ }^{76}$ MacInnes aside, white commentators seldom thought to question the normative nature of indigenous masculine ideals. A model of white men as industrious, responsible, equanimous, and continent was used unreflectively as a yardstick with which to find West Indian men wanting. Nor did West Indian men serve as a necessary "Other' against which to define either masculinity or white British identity. ${ }^{77}$ Understandings of West Indian masculinity were affected by, but had no discernible effect on, evolving norms for white men in this period so that, for example, West Indians went unmentioned in the wider debate on companionate marriage taking place outside the race relations literature. Likewise, the very unwillingness of white commentators to rethink the nature of national identity in light of mass immigration showed midcentury Britain to be a nation all too much at ease with itself. Complacency came readily to a privileged majority.

Whereas most whites literally prejudged West Indian men and saw no reason to revise attitudes unaltered in their essentials since colonial days, the perspective of West Indian men underwent considerable change. Many had arrived in Britain considering themselves to be British and expecting to be treated as such, yet they found the very rudiments of respectability - a job, a wife, a home, independence-being withheld by a host society which betrayed their expectations. The prejudice they encountered concerning their work habits and their family life, their sexual relations and their supposedly violent inclinations may help explain why such observers as Stuart Hall, Nancy Foner, and John Western identified greater dissatisfaction among male than female West Indian immigrants in the following decades. Some second generation immigrants expressed their disillusionment in dramatic fashion in the confrontational politics of Rastafarianism and riots, in turn confirming the worst suspicions of whites concerning the deviance of West Indian men. But it was their fathers who, in their comparatively undemonstrative manner, had begun to reject assimilation as an undesirable and in any case unattainable goal. Their hard task was to fashion a masculinity at once respect-

${ }^{76}$ For variations on the theme of masculinity in crisis, see Klaus Theweleit, Male Fantasies, 2 vols. (Minneapolis, 1987); Bram Dijkstra, Evil Sisters: The Threat to Female Sexuality and the Cult of Manhood (New York, 1996); Michael Kimmel, Manhood in America: A Cultural History (New York, 1996); and Graham Dawson, Soldier Heroes: British Adventure, Empire and the Imagining of Masculinities (London, 1994).

${ }^{77}$ For the definition of Britishness against a black "Other," see Hall, White, Male and Middle Class, pp. 207-8; Tabili, "We Ask for British Justice," p. 10; and Sinha, Colonial Masculinity, p. 7. 
able and black, so severing the association between British gentlemanliness and masculine respectability and thereby reconciling their racial and gender identities. West Indian masculinity was entering its postcolonial phase. $^{78}$

${ }^{78}$ Stuart Hall cited in Phillips and Phillips, Windrush, pp. 379-80; Foner, Jamaica Farewell, chap. 2; Western, A Passage to England, p. 89. For Rastafarianism, see Ernest Cashmore, Rastaman: The Rastafarian Movement in England, rev. ed. (London, 1983). 